УДК 617.52-001.4:616.833.15:615.21] - 073.7

DOI 10.11603/2311-9624.2019.2.10396

(С). Р. Назаревич, О. Я. Мокрик, Ю. М. Мельничук

Львівський національний медичний університет імені Данила Галицького

zahn2008@ukr.net

\title{
Визначення больової перцепції і ступеня порушень провідності другої гілки трійчастого нерва у хворих із переломами кісток середньої зони обличчя на тлі дії транскраніальної електростимуляції та препарату «Келтікан N»
}

Резюме. Лікування переломів кісток середньої зони обличчя є однією з актуальних проблем у хірургічній стоматології та щелепно-лицевій хірургії. Це зумовлено тим, ушкодження кісток середньої зони обличчя за частотою займають 2-ге місце серед переломів щелепно-лицевої ділянки (Щлд) і сягають 20-35 \%, при цьому тенденції до зниження їх кількості не відзначається.

Мета дослідження - оптимізувати діагностично-лікувальний процес у хворих із переломами кісток середньої зони обличчя на етапі післяопераційної реабілітації шляхом упровадження методу електродіагностики порушень провідності другої гілки трійчастого нерва, прийому препарату «Келтікан N» та застосування транскраніальної електростимуляції.

Матеріали і методи. Проведено оцінку стану електропровідності 50 хворих з переломами верхньої щелепи, тіла та дуги виличної кістки, яких лікували за допомогою ортопедичних методів. Ми запропонували методи діагностики та фізіотерапевтичного лікування і медикаментозний препарат, який поліпшує ефективність лікування пацієнтів із переломами кісток середньої зони обличчя. Проведено порівняння стану електропровідності другої гілки трійчастого нерва на тлі прийому препарату «Келтікан N» та сеансів транскраніальної електростимуляції.

Результати досліджень та їх обговорення. У перший день госпіталізації відмічається значне порушення провідності другої гілки трійчастого нерва в усіх хворих. На час закінчення лікування в основній групі відмічено значну позитивну динаміку покращення електропровідності другої гілки трійчастого нерва, на що вказує відновлення показників порога відчуттів (ПВ), порога болю (ПБ) та рівня витривалості болю (РВБ) майже до рівня неушкодженого контрлатерального боку. Отримані результати дозволяють щелепно-лицевим хірургам застосовувати в клінічній практиці препарат «Келтікан N» та метод транскраніальної електростимуляції.

Висновки. За допомогою апарата для електродіагностики «PulpTester DY310» можна простежити процес відновлення провідності другої гілки трійчастого нерва шляхом вимірювання порога чутливості й порога болю та больову перцепцію за рівнем витривалості до болю. При поєднаному використанні препарату «Келтікан N» та транскраніальної електростимуляції спостерігають значне покращення показників порога чутливості й порога болю другої гілки трійчастого нерва та підвищення рівня витривалості до болю; відновлення електропровідності в травматично ушкодженій гілці трійчастого нерва є свідченням активних процесів репарації у ньому. Використання препарату «Келтікан N» та транскраніальної електростимуляції є виправданими у комплексному лікуванні переломів кісток середньої зони обличчя, що супроводжуються ушкодженням другої гілки трійчастого нерва.

Ключові слова: переломи кісток середньої зони обличчя; електродіагностика; друга гілка трійчастого нерва; препарат «Келтікан N»; метод транскраніальної електростимуляції.

(С). Р. Назаревич, О. Я. Мокрик, Ю. Н. Мельничук

Львовский национальный медицинский университет имени Данила Галицкого

\section{Определение болевой перцепции и степени нарушения проводимости второй ветви тройничного нерва у больных с переломами костей средней зоны лица на фоне действия транскраниальной электростимуляции и препарата «Келтикан N"}

Резюме. Лечение переломов костей средней зоны лица является одной из актуальных проблем в хирургической стоматологии и челюстно-лицевой хирургии. Это обусловлено тем, что повреждения 
костей средней зоны лица по частоте занимают 2-е место среди переломов челюстно-лицевой области (ЧЛО) и становлят 20-35 \%, при этом тенденции к снижению их количества не отмечается.

Цель исследования - оптимизировать диагностически-лечебный процесс у больных с переломами костей средней зоны лица на этапе послеоперационной реабилитации путем внедрения метода электродиагностики нарушений проводимости второй ветви тройничного нерва, приема препарата «Келтикан N» и применения транскраниальной электростимуляции.

Материалы и методы. Проведена оценка состояния электропроводности 50 больных с переломами верхней челюсти, тела и дуги скуловой кости, которых лечили с помощью ортопедических методов. Нами предложены методы диагностики и физиотерапевтического лечения и медикаментозный препарат, который улучшает эффективность лечения пациентов с переломами костей средней зоны лица. Проведено сравнение состояния электропроводности второй ветви тройничного нерва на фоне приема препарата «Келтикан N» и сеансов транскраниальной электростимуляции.

Результаты исследований и их обсуждение. В первый день госпитализации отмечается значительное нарушение проводимости второй ветви тройничного нерва у всех больных. К времени окончания лечения в основной группе отмечено значительно положительную динамику улучшения электропроводности второй ветви тройничного нерва, на что указывает восстановления показателей порога ощущений (ПВ), порога боли (ПБ) и уровня выносливости боли (РВБ) почти до уровня неповрежденной контрлатеральной стороны. Полученные результаты позволяют челюстно-лицевым хирургам применять в клинической практике препарат «Келтикан N» и метод транскраниальной электростимуляции.

Выводы. С помощью аппарата для электродиагностики «PulpTester DY310» можно проследить процесс восстановления проводимости второй ветви тройничного нерва путем измерения порога чувствительности и порога боли, болевую перцепцию по уровню выносливости к боли. При совместном использовании препарата «Келтикан N» и транскраниальной электростимуляции наблюдается значительное улучшение показателей порога чувствительности и порога боли второй ветви тройничного нерва и повышения уровня выносливости к боли; восстановление электропроводности в травматично поврежденной ветке тройничного нерва является свидетельством активных процессов репарации в нем. Использование препарата «Келтикан N» и транскраниальной электростимуляции оправданы в комплексном лечении переломов костей средней зоны лица, сопровождающихся повреждением второй ветви тройничного нерва.

Ключевые слова: переломы костей средней зоны лица; электродиагностика; вторая ветвь тройничного нерва; препарат «Келтикан N», метод транскраниальной электростимуляции.

CM. R. Nazarevych, O. Y. Mokryk, Y. M. Melnychyk

Danylo Halytskyi Lviv National Medical University

\section{The determination of pain perceptance and conduction disturbance degree of the second branch of the trigeminal nerve in patients with bones fractures in the middle zone of the face during transcranial electrostimulation and Keltican $\mathrm{N}$ medication}

Summary. The treatment of midline fractures is one of the pressing problems of surgical dentistry and maxillofacial surgery [4]. This is due to the fact that the injuries of the bones of the middle area of the face in frequency occupy the second place among fractures of the maxillofacial area (thyroid) and reach 20-35 \%, with a tendency to decrease their number is not observed.

The aim of the study - to optimize the diagnostic and therapeutic process in patients with fractures of the bones of the middle zone of the face at the stage of postoperative rehabilitation by introducing the method of electrodiagnostics of conduction disorders of the second branch of the trigeminal nerve, taking the drug «Keltikan N» and applying transcranial electrostimulation.

Materials and Methods. We conducted our evaluation of the electrical conductivity of 50 patients with fractures of the upper jaw, zygomatic bone body and arch, which treated using orthopedic methods. We proposed methods of diagnosis, physiotherapy and medication drug that improves the effectiveness of treatment in patients with middle zone face fractures. The state of electrical conductivity of the second branch of the trigeminal nerve was compared when receiving the drug «Keltikan N» and sessions of transcranial electrostimulation.

Results and Discussion. On the first day of hospitalization, all patients have a marked conduction violation of the second branch of the trigeminal nerve. At the end of treatment in the main group, a significant positive dynamics was observed in improving the electrical conductivity of the second branch of the trigeminal nerve, 


\section{Хірургічна стоматологія}

as indicated by the restoration of sensitivity threshold (ST), pain threshold (PT), and the pain endurance level (PEL) almost to the level of intact contholateral side. The results allow maxillofacial surgeons to use in clinical practice medicine «Keltikan N" and the method of transcranial electrostimulation.

Conclusions. Using the PulpTester DY310 electrodiagnostic, you can follow the process of restoring the conduction of the second branch of the trigeminal nerve by measuring the threshold of sensitivity and threshold of pain and pain perception according to the level of endurance to pain. With the combined use of the drug «Keltikan N» and transcranial electrostimulation, there is a significant improvement in the threshold of sensitivity and pain threshold of the second branch of the trigeminal nerve and increased pain relief; restoring electrical conductivity in the traumatically damaged branch of the trigeminal nerve is evidence of active repair processes in it. The use of the drug «Keltikan N» and transcranial electrostimulation are justified in the complex treatment of fractures of the bones of the middle area of the face, which are accompanied by damage to the second branch of the trigeminal nerve.

Key words: bones fractures in the middle zone of the face; electrodiagnostics; the second branch of the trigeminal nerve; Keltikan N; to the method of transcranial electrostimulation.

Вступ. Лікування переломів кісток середньої зони обличчя є однією з актуальних проблем у хірургічній стоматології та щелепно-лицевій хірургії [4]. Це зумовлено тим, ушкодження кісток середньої зони обличчя за частотою займають 2-ге місце серед переломів щелепно-лицевої ділянки (Щлд) і сягають 20-35 \%, при цьому тенденції до зниження їх кількості не відзначається [10, 15-19]. Ми провели аналіз історій хвороб пацієнтів, які перебували на стаціонарному лікуванні у відділенні ЩЛХ Комунальної міської клінічної лікарні швидкої медичної допомоги м. Львова за період 32014 до 2016 року. В загальній структурі травматичних ушкоджень лицевого черепа переломи кісток середньої зони обличчя становили 30,9 \% [8].

Як відомо, цей вид травми дуже часто супроводжується таким ускладненням як ушкодження другої гілки трійчастого нерва, тому питання якнайшвидшого відновлення його функції залишається на сьогодні відкритим $[1,19]$. Окрім того, за свідченнями багатьох авторів, травматизація другої гілки трійчастого нерва може бути зумовлена помилками хірургічного лікування, наприклад під час операції остеосинтезу, гайморотомії [21-23].

При травмі другої гілки трійчастого нерва виникають фізіологічні та морфологічні зміни у тканинах обличчя. Функція нерва порушується при його безпосередньому травмуванні кістковими уламками під час ушкодження нижньочного каналу, а також при його компресії післяопераційним набряком або гематомою у просвіті каналу [4, 5, 9, 22]. Клінічно це проявляється анестезією, гіпостезією, гіперестезією, або ж парестезією в ділянках іннервації другої гілки трійчастого нерва. Хворі скаржаться на відчуття оніміння, повзання "мурашок», поколювання, печіння в ділянці верхньої губи, носа, під очницею, в ділянці виличної кістки. Деколи може виникати невралгічний біль у вищевказаних ділянках, що значно погіршує психоемоційний стан хворого [3, 5, 9].

За свідченнями багатьох авторів, швидкість процесу реіннервації нерва, головним чином, залежить від тривалості механічної травми нерва, яка веде за собою порушення його кровопостачання та токсичний вплив продуктів розпаду ділянки тканин, які ним іннервуються [21, 22].

Вивчаючи фахові літературні джерела, які присвячені даній тематиці, ми дійшли висновку, що завдання оптимізації післятравматичного відновлення другої гілки трійчастого нерва вирішене на сьогодні недостатньо. При лікуванні хворих із переломами кісток середньої зони обличчя основну увагу приділяють ефективній репозиції та фіксації уламків верхньощелепної та виличної кісток, а об'єктивній діагностиці та ефективному лікуванню ушкодженої другої гілки трійчастого нерва відводиться досить таки незначна роль [2].

Клініцисти проводять медикаментозну терапію для усунення больового синдрому, симптомів гострого запалення, зумовленого травматичним ушкодженням тканин, 3 метою профілактики інфекційних ускладнень. Сучасна стратегія лікування захворювань периферичної нервової системи передбачає створення умов для ремієлінізації, регенеративного і колатерального спраутингу, а також стимуляцію цих процесів, що може забезпечити екзогенне надходження піримідинових нуклеотидів, таких як цитидинмонофосфат (ЦМФ) і уридинтрифосфат (УТФ). Також ЦМФ 
$€$ попередником нуклеїнових кислот (ДНК і РНК), які, у свою чергу, є основними елементами клітинного метаболізму. УТФ діє як кофермент в синтезі гліколіпідів, нейронних структур і мієлінової оболонки, доповнюючи дію ЦМФ. Крім того, УТФ діє як джерело енергї в процесі скорочення м’язів. ЦМФ і УТФ беруть участь в синтезі фосфоліпідів і гліколіпідів, 3 яких в основному і складається мієлінова оболонка та інші нервові структури. Це призводить до інтенсифікації метаболічної активності, сприяє процесу регенерації мієлінової оболонки, регулюючи демієнілінізацію при периферійних нервових ушкодженнях. В цілому поєднана дія ЦМФ і УТФ сприяє регенерації мієлінової оболонки, правильному проведенню нервового збуждения та відновленню м'язової трофіки. Препаратом вибору, який містить ЦМФ та УТФ, є «Келтікан N». Практичні лікарі вказують на переваги цього препарату в лікуванні полінейропатій різноманітної етіології. Швидкий знеболювальний ефект та покращення сенсорної функції помітили при лікуванні діабетичної невропатії чутливих нервів нижніх кінцівок [24].

Однак варто враховувати, що окрім травми другої гілки трійчастого нерва, переломи кісток середньої зони обличчя у всіх випадках супроводжуються черепно-мозковою травмою різного ступеня тяжкості [2, 8, 10]. Тому як медикаментозна, так і фізіотерапія повинні бути спрямовані не тільки на корекцію функцій периферійної, але й центральної нервової систем. На ранньому етапі післяопераційної реабілітації лікарі здебільшого призначають місцеві фізіотерапевтичні методи лікування: УВЧ-терапію, СВЧ-терапію, електрофорез йодиду калію [7]. Однак в жодному із клінічних випадків не було застосовано фізіотерапевтичного впливу на механізми регуляції функції центральної нервової системи, яка відіграє визначальну роль в модуляції та перцепції больового синдрому у хворих. За даними власних клінічних спостережень при виписці хірургічних стоматологічних хворих на амбулаторне доліковування, в них у 59,5 \% випадків зберігаються клінічні прояви порушень функцій периферійної та вегетативної нервової систем.

Багато авторів підтвердили клінічну ефективність застосування методу транскраніальної електроаналгезії, оригінальною модифікацією якої є транскраніальна електростимуляція (TEC) [6, 7, 20]. Цей фізіотерапевтичний метод забеспечує вплив не тільки на ушкоджену ділянку черепа, але й на організм в цілому. Під час проведення сеансів TEC у хворих нормалізується робота центрів адаптаційної системи організму, локалізованих в серединних структурах головного мозку (гіпоталамусі, лімбічній системі) та вибірково активізуються опіоїдні структури головного мозку (стимулюється продукція $\beta$-ендорфінів). Також, згідно з даними багатьох авторів, здійснюється вплив на гіпоталамо-гіпофізарну систему, в якій виробляється спектр нейрогормонів, які координують діяльність органів і систем в умовах стресу (адренокортикотропного гормону, пролактину, вазопресину). При цьому знеболювальний і седативний ефекти $€$ лише одним із компонентів багатовекторної дії ТЕС. У режимі мезодіенцефальної модуляції проявляється іï антистресова дія та стимулюються репаративні процеси - нормалізується мікроциркуляція, оптимізується остеогенез.

Метою дослідження було оптимізувати діагностично-лікувальний процес у хворих із переломами кісток середньої зони обличчя на етапі післяопераційної реабілітації шляхом впровадження методу електродіагностики порушень провідності другої гілки трійчастого нерва, прийому препарату «Келтікан N» та застосування транскраніальної електростимуляції.

Матеріали і методи. Проведено обстеження 50 пацієнтів із переломами лицевих кісток середньої зони обличчя, які перебували на лікуванні у відділенні щелепно-лицевої хірургії Комунальної міської клінічної лікарні швидкої медичної допомоги м. Львова за період 3 2014 до 2017 року.

У загальній структурі травматичних ушкоджень лицевого черепа в обстежуваних хворих переломи кісток середньої зони обличчя становили переломи верхньої щелепи - 7,2 \%, виличної кістки та дуги - 21,9 \%, кісток носа - 1,8 \%. За досліджуваний період у хворих із переломами верхньої щелепи (34 чоловіків 79,1 \% і 9 жінок - 20,9 \%) виявляли таку їх локалізацію: за Le For I - у 12 випадків, за Le For II - в 23 випадків, за Le For III - у 8 випадках. Розподіл пацієнтів за віковими групами був таким: підлітковий - 2 хворих (4,6 \%), юнацький - 6 хворих (13,9 \%), зрілий (І період) - 14 хворих (32,5 \%), зрілий (II період) - 18 хворих (41,8 \%), похилий - 3 хворих (6,9 \%). Переломи верхньої щелепи характерні для найбільш працездатної вікової групи населення (21-50 років), вони траплялися у 32 (74,3 \%) хворих. 
Тривалість стаціонарного лікування пацієнтів із травматичними переломами кісток середньої зони обличчя виявилася такою: у хворих $з$ переломом верхньої щелепи за Le For I, поєднаний зі струсом головного мозку,

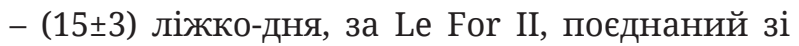
струсом головного мозку, - (19 \pm 2$)$ ліжко-дня, за Le For III, поєднаний зі струсом головного моз-

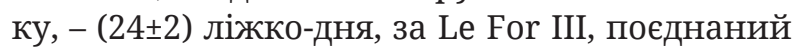
із забоєм головного мозку - (32 \pm 4$)$ ліжко-дня; у хворих з ізольованим переломом виличної кістки чи дуги становила в середньому $(8 \pm 2)$ ліжко-дня. При поєднанні зі струсом головного мозку - (13 22) ліжко-дня, із забоєм головно-

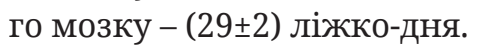

Серед оперативних методів лікування переломів верхньощелепних кісток ми найчастіше застосовували методику остеосинтезу із використанням титанових міні-пластин. У 9 \% випадків проводили ревізію верхньощелепного синуса 3 метою видалення 3 цього анатомічного утворення сторонніх тіл, коренів зубів, кісткових фрагментів, ушкоджених стінок верхньощелепної пазухи. Переважно (82 \% випадків) репозицію відламків виличних кісток та дуг здійснювали ми за допомогою гачка Лімберга чи щипців Duchange.

Хворих, залежно від застосованих методів консервативного лікування на етапі післяопераційної реабілітації, поділили на дві дослідні групи - основну та контрольну. До основної групи увійшло 25 пацієнтів, яким через добу після операцій для пришвидшення розсмок- тування гематом очниці та підочноямкового простору, профілактики виникнення спайкових процесів у ділянці ушкодження гілки верхньощелепного нерва на дні очниці (n. infraorbitalis), вводили парабульбарно до підочноямкової борозни, де залягає одноіменний нерв та артерія, фібринолітичний препарат «Гемаза» (рекомбінантну проурокіназу) - по $5000 \mathrm{ME}$ в 0,5 мл 0,9 \% розчину хлориду натрію 1 раз на добу упродовж 3-4 діб.

у післяопераційному періоді усі хвоpi групи приймали парентерально (внутрішньом'язово) остеотропний антибіотик «Кліндаміцин» упродовж 7 діб; нестероїдний протизапальний препарат «Кетопрофен» - по 100 мг 2 рази на добу внутрішньом'язово упродовж 5-6 діб; протинабрякову терапію (L-лізину есцинату - внутрішньовенно по 5-10 мл препарату, розведеного у 10-20 мл 0,9\% розчину натрію хлориду 1 раз на добу упродовж 4-5 діб). Препарат «Келтікан N» вводили з третьої доби лікування парентерально (внутрішньом'язово) у дозі 2 мл 1 раз на добу протягом тижня, далі переходили на ентеральне застосування - по 2 капсули 2 раза на добу. Усім хворим основної групи через день після операції розпочинали курс транскраніальної електростимуляції, щоденно, 10-14 сеансів (рис. 1).

У контрольній групі в якості післяопераційного медикаментозного супроводу всі хворі також приймали парентерально (внутрішньом'язово) остеотропний антибі-

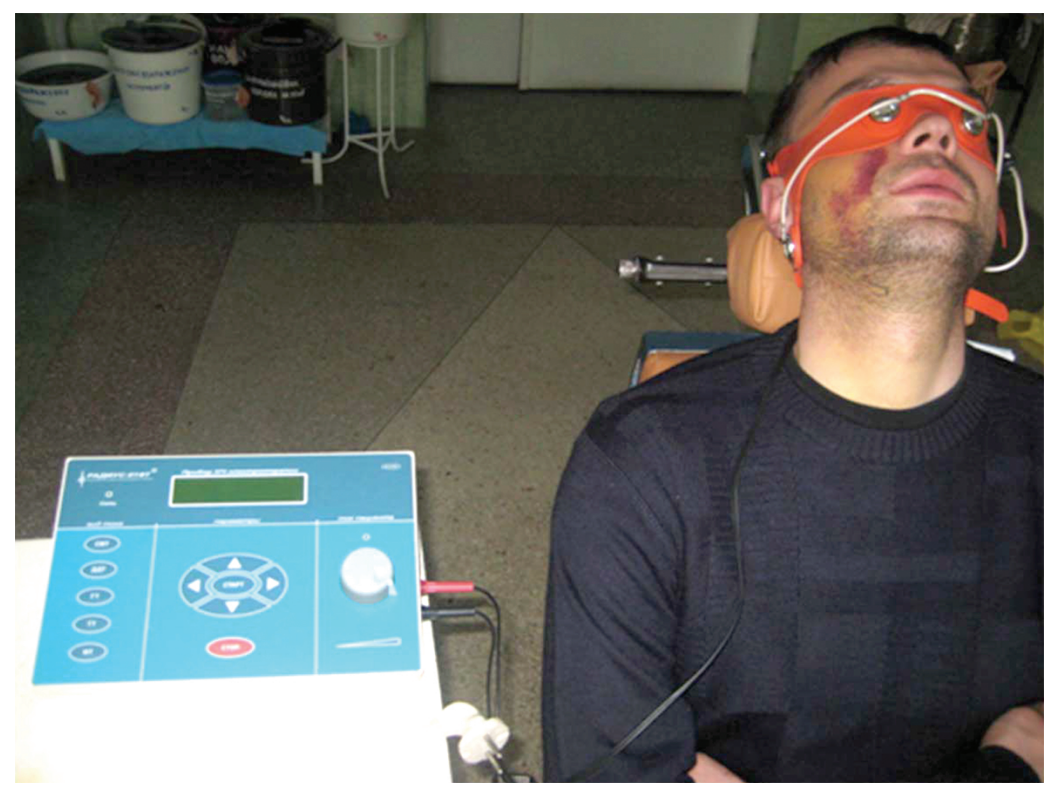

Puc. 1. Сеанс транскраніальної електростимуляції хворого із травматичним ушкодженням кісток середньої зони обличчя. 
тик «Кліндаміцин» упродовж 7 діб; нестероїдний протизапальний препарат «Кетопрофен» - по 100 мг 2 рази на добу внутрішньом'язово протягом 5-6 діб, протинабрякову терапію (L-лізину есцинату - внутрішньовенно по 5-10 мл препарату, розведеного у 10-20 мл $0,9 \%$ розчину натрію хлориду 1 раз на добу упродовж 4-5 діб). Для активізації метаболічних процесів у нервовій тканині призначали комплекс вітамінів $\mathrm{B}_{1}, \mathrm{~B}_{6}, \mathrm{~B}_{12}$ - ін'єкції внутрішньом'язово по 2 мл 3 рази на тиждень протягом 2 тижнів. Місцево хворі отримували фізіотерапевтичні процедури: через 1 добу після операції розпочинали курс УВЧ-терапії на ділянку ураження (процедури тривалістю від 10 до 20 хв щоденно, в субтермічних дозах (з легким відчуттям тепла), на курс лікування 6-7 процедур.

3 метою об'єктивізації діагностичного процесу хворим обох груп здійснювали визначення електропровідності другої гілки трійчастого нерва. У роботі застосовано методику О. С. Барило та Р. Л. Фурман (2016), які оцінювали стан електропровідності другої гілки трійчастого нерва у хворих із переломами виличної кістки після операції репозиції відламків [25]. Зазначені автори, у свою чергу, використали розробки В. Е. Гречко, О. Б. Гораніна, Н. А. Синявої (1980).

У роботі застосувати метод визначення порогів больової чутливості (ПБЧ), який грунтується на зіставленні сили електричного подразника, наявність якого викликає в пацієнта відповідні відчуття. Однією із переваг даного подразника є можливість дозування та регулювання сили і тривалості дії струму, а також багаторазового неінвазивного застосування. Для проведення даного дослідження ми обрали пульптестер «Pulp Tester DY310».

Це пояснюється тим, що вітчизняні автори розробили просту у виконанні та об'єктивну методику дослідження провідності гілок трійчастого нерва саме на цьому приладі. «Pulp Tester DY310» - це апарат, який первинно створений саме для класичної електроодонтодіагностики. Науковці, модифікувавши спосіб дії апарата для диференційної діагностики рівня патофізіологічних процесів у нервовій системі, зуміли визначати чутливість до подразнення електричним струмом шкірних покривів у зоні іннервації другої гілки трійчастого нерва у місці її найближчого розташування до шкіри (в проекції підочноямкового отвору).
У своїй роботі при визначенні порогів чутливості ми використовували наступні критеpiї, на які орієнтуються хворі:

1. Поріг відчуттів (ПО) - найслабші відчуття, які першими з'являються при збільшенні інтенсивності подразника;

2. Поріг болю (ПБ) - відчуття, при яких тільки з'являється біль неприємного відтінку;

3. Рівень витривалості болю (РВБ) - неприємні відчуття, подальшого збільшення інтенсивності яких пацієнт відчувати не бажає. Цей показник вказує на емоційну складову больового сприйняття хворим (перцепцію болю) та рівень функціональної активності центральних ендогенних механізмів гальмування болю (опіатергічних, серотонінергічних, ГАМК - ергічних).

3 метою порівняння отриманих показників ми проводили аналогічне дослідження 3 контрлатерального боку обличчя. Згідно 3 методикою, дослідження виконували тричі й вираховували середній результат. Отримані результати порівнювали із середньостатистичними значеннями та даними із контрлатерального боку. Отже, за динамікою порогів больової чутливості в ділянці іннервації другої гілки трійчастого нерва можна визначити порушення провідності нервового імпульсу в основних чутливих групах волокон другої гілки трійчастого нерва, що дозволяє визначити ступінь порушення його функції. Електродіагностику проводили тричі за період знаходження хворого в стаціонарі: на 1; 7 та 14-ту доби післяопераційного періоду. Статистичну обробку результатів дослідження виконували з використанням t-критерію Стьюдента на комп’ютері за допомогою методів варіаційної статистики (програми Statistica 8). Різницю вважали достовірною при $\mathrm{p}<0,05$.

Результати досліджень та іх обговорення. Після обстеження хворих порівняльних груп було виявлено такі результати. Через добу після операційного втручання в обох клінічних групах діагностовано значне підвищення порога відчуттів (ПВ), порога болю (ПБ) та зниження рівня витривалості болю (РВБ): ПВ $(40,2 \pm 1,7)$ МА, ПБ - $(53,6 \pm 2,1)$ мА, РВБ - $(72,8 \pm 1,9)$ мА, що свідчило про значне порушення провідності другої гілки трійчастого нерва порівняно 3 нормою $(\mathrm{p}<0,001)$ та недостатню функціональну активність антиноцицептивної системи в цих хворих. Характерно, що вказані величини (ПВ, ПБ та РВБ) протягом періоду лікування зазнавали позитивних змін, але цей 
процес був повільним у хворих контрольної групи. В них на 7-му добу спостереження було незначне покращення чутливості в зоні іннервації другої гілки трійчастого нерва на боці ураження та збереження рівня больової перцепції ( $>>0,05)$ : ПВ - $(38,5 \pm 1,9)$ мА, ПБ - $(48,1 \pm 2,4)$ мА, РВБ - $(70,4 \pm 1,6)$ мА (рис. 2). На 14-ту добу статистично вірогідно змінився $(\mathrm{p}<0,05)$, порівняно $з$ першою добою післяопераційного періоду, показник порога відчуттів - $(32,2 \pm 1,5)$ мА та порога болю - $(46,3 \pm 1,7)$ мА. Зміни показника РВБ були менш виражені порівняно з попередніми термінами спостереження (p>0,05).

В основній групі на 7 добу післяопераційного періоду на тлі розсмоктування гематоми на зменшення набряку м’яких тканин у ділянці очниці спостерігалось статистично вірогідне $(\mathrm{p}<0,05)$ покращення сенсорної функції підочноямкового нерва, однак показник толерантності до болю змінювався менш активно: РВБ до болю становив $(71,1 \pm 1,9)$ мА (на 1 добу) та $(59,8 \pm 2,6)$ мА (на 7 добу). Надалі виявлено більш виражену динаміку покращення електропровідності другої гілки трійчастого нерва та зростання больової толерантності $(\mathrm{p}<0,01)$, про що свідчило прогресуюче відновлення показників порога тактильних відчуттів (ПВ) $(17,3 \pm 1,4)$ мА, порога болю (ПБ) - $(32,1 \pm 1,5)$ мА та РВБ - $(50,9 \pm 1,8)$ мА (рис. 3$)$. Аналізуючи отримані результати дослідження, можна конста-

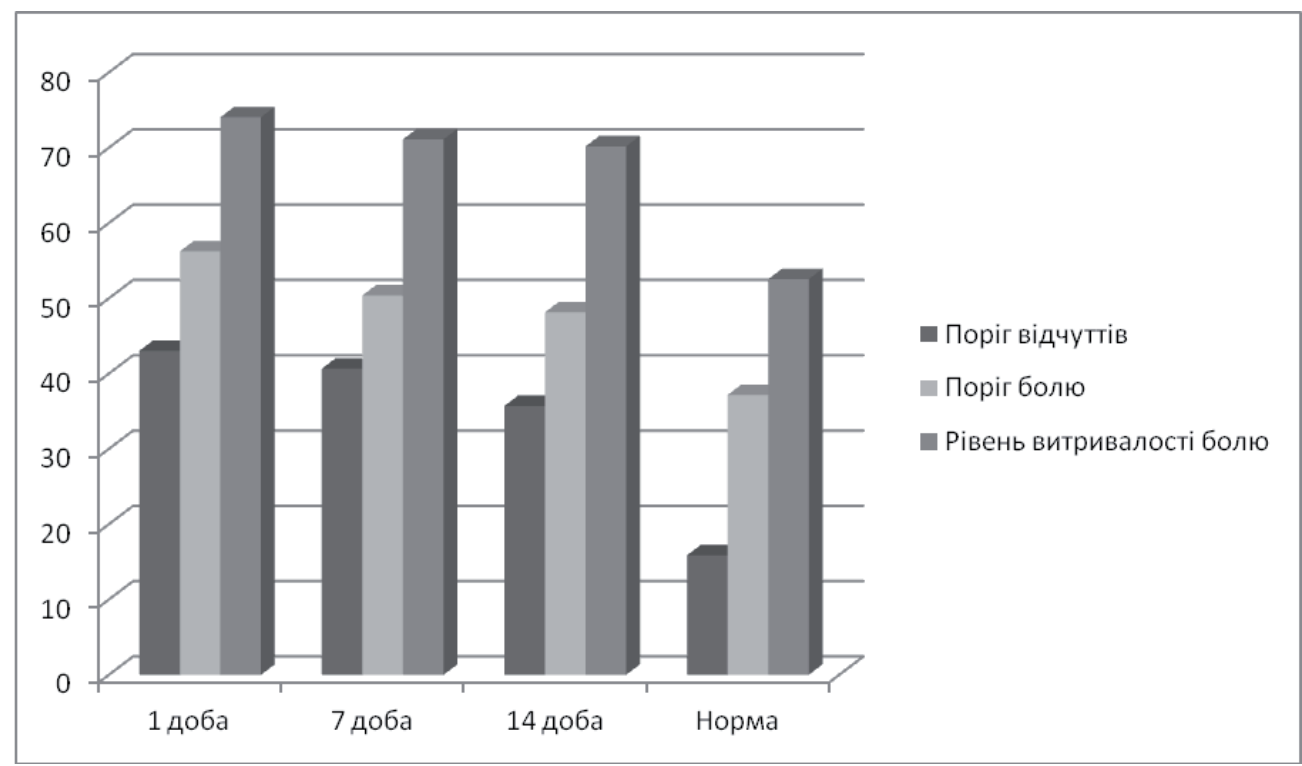

Puc. 2. Показники електродіагностики другої гілки трійчастого нерва у хворих контрольної групи.

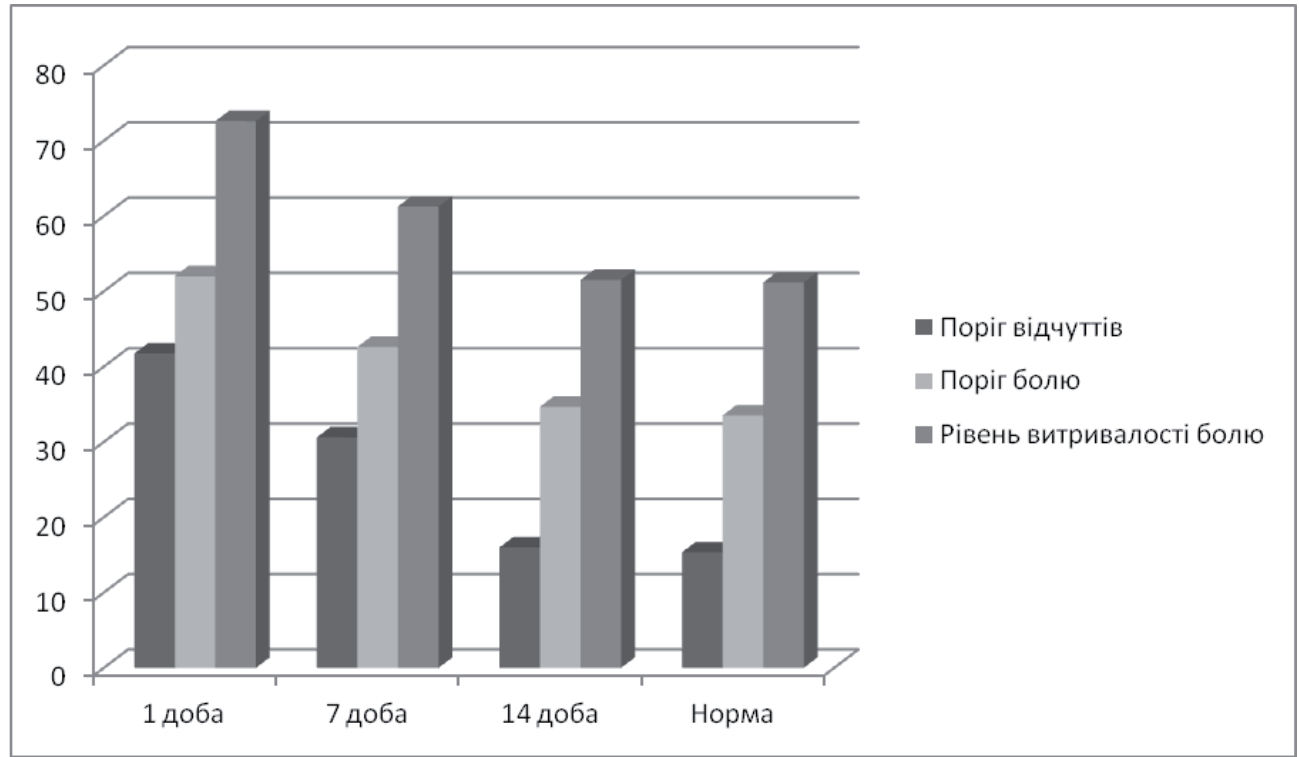

Puc. 3. Показники електродіагностики другої гілки трійчастого нерва у хворих основної групи. 
тувати, що в основній групі під взаємопотенціюючим впливом препарату «Келтікан N» та транскраніальної електростимуляції відмічається значне покращення функціонування другої гілки трійчастого нерва, активізація центральних антибольових механізмів.

Аналізуючи дані діаграми, можна зробити висновок, що показники порога відчуттів, порога болю та рівні витривалості болю на час закінчення стаціонарного лікування (14-та доба) можуть наблизитися до рівня показників норми. Результати наших досліджень узгоджуються з отриманими клінічними даними інших науковців, які вивчали цю проблему [25]. Виявлено, що поєднання запропонованого медикаментозного та фізіотерапевтичного лікування хворих із ушкодженнями другої гілки трійчастого нерва значно покращує його функцію.

Висновки. 1. За допомогою апарата для електродіагностики «PulpTester DY310» можна

\section{Список літератури}

1. Браславец А. Я. Неотложная неврология : учеб. пособ. для студентов, врачей-интернов, клинических ординаторов, магистров / А. Я. Браславец. - Харьков, 2006. - 170 c.

2. Воскресенская О. Н. Сотрясение головного мозга: клиника, диагностика, лечение / О. Н. Воскресенская, И. В. Дамулин // Российский медицинский журнал. - 2015. - № 5. - С. 53-56.

3. Неврология : национальное руководство / Е. И. Гусев, А. Н. Коновалов, В. И. Скворцова, А. Б. Гехт. - М. : ГЭОТАР-Медиа, 2009. - 1040 с.

4. Структура травм челюстно-лицевой области на примере г. Ставрополя / Е. В. Елисеева, К. С. Гандылян, С. М. Карпов [и др.] // Актуальные вопросы стоматологии : 49 Всеросс. науч.-практ. конференция : материалы конф. - Ставрополь, 2014. - C. 211-214.

5. Карлов В. А. Неврология : руководство для врачей. - 3-е изд. / В. А. Карлов. - М. : Мединформагентство, 2011. -664 с.

6. Лепилин А. В. Применение чрескожной электронейростимуляции в комплексе лечения больных с переломами нижней челюсти / А. В. Лепилин, Г. Р. Бахтеева, Н. Л. Ерокина // Стоматология. - 2007. - Т. 86, № 2. - С. 54-56.

7. Мокрик О. Я. Сучасні досягнення фізіотерапевтичного лікування больового синдрому у хворих із патологічними процесами в щелепно-лицевій ділянці / О. Я. Мокрик, М. Р. Назаревич // Медична гідрологія та реабілітація. - 2012. - Т. 10, № 1. - С. 19-23. 8. Назаревич М. Р. Ретроспективне вивчення особливостей пошкоджень кісток середньої зони обличчя у стаціонарних хворих та застосованих підходів до їх лікування / М. Р. Назаревич // Актуальні проблеми сучасної медицини: вісник української медичної стоматологічної академії (Полтава). - простежити процес відновлення провідності другої гілки трійчастого нерва шляхом вимірювання порога чутливості й порога болю та больову перцепцію за рівнем витривалості до болю.

2. При поєднаному використанні препарату «Келтікан N» та транскраніальної електростимуляції спостерігається значне покращення показників порога чутливості й порога болю другої гілки трійчастого нерва та підвищення рівня витривалості до болю; відновлення електропровідності в травматично ушкодженій гілці трійчастого нерва є свідченням активних процесів репарації у ньому.

3. Використання препарату «Келтікан N» та транскраніальної електростимуляції $є$ виправданими у комплексному лікуванні переломів кісток середньої зони обличчя, що супроводжуються ушкодженням другої гілки трійчастого нерва.

2017. - T. 17, № 2. - С. 132-136.

9. Нервові хвороби / за ред. С. М. Віничука, Є. Г. Дубенка. - К. : Здоров’я, 2001. - 696 с.

10. Сиволапов К. А. Клинико-социальные аспекты травматических повреждений средней зоны лица / К. А. Сиволапов, Е. В. Харченко // Актуальные проблемы стоматологии и смежных областей : материалы науч.-практ. конф. - Новосибирск, 2001. - C. 25-32.

11. Тимофеев А. А. Изучение состояния нижнего альвеолярного нерва при повреждениях нижней челюсти в динамике проводимого лечения. Часть 1 / А. А. Тимофеев, В. Л. Леснухин // Современная стоматология. - 2009. - № 3. - С. 109-115.

12. Тимофеев А. А. Изучение состояния нижнего альвеолярного нерва при повреждениях нижней челюсти в динамике проводимого лечения. Часть 2 / А. А. Тимофеев, В. Л. Леснухин // Современная стоматология. - 2009. - № 4. - С. 76-80.

13. Тимофеев А. А. Использование цветной стереолитографии в диагностике поражений периферических ветвей тройничного нерва / А. А. Тимофеев, Е. П. Весова // Современная стоматология. - 2006. № 1. - С. 113-116.

14. Тимофеев А. А. Клинико-патофизиологические подходы к классификации поражений в системе тройничного нерва / А. А. Тимофеев, Е. П. Весова // Современная стоматология. - 2010. - № 4. - С. 100 101.

15. Тимофеев А. А. Руководство по челюстно-лицевой хирургии и хирургической стоматологии / А. А. Тимофеев. - К., 2012. - 1048 с.

16. Тимофеев А. А. Челюстно-лицевая хирургия / А. А. Тимофеев. - К.: Медицина, 2010. - 576 с.

17. Умаров О. М. Общая статистическая характеристика сочетанной травмы челюстно-лицевой облас- 
ти / О. М. Умаров // Врач-аспирант. - 2012. - Т. 50, № 1.1. - С. 221-224.

18. Хірургічна стоматологія та щелепно-лицева хірургія : підручник Т. 1 / [В. О. Маланчук, О. С. Воловар, І. Ю. Гарляускайте та ін.]. - К. : ЛОГОС, 2011. -672 c.

19. Хирургическая стоматология : учебник / под ред. Т. Г. Робустовой. - изд. 4-е. - М. : Медицина, 2010. $687 \mathrm{c}$.

20. Цукурова Л. А. Транскраниальная электростимуляция при лечении больных с ишемическим инсультом в раннем восстановительном периоде / Л. А. Цукурова, М. А. Барабанова, Г. Т. Музлаев // Актуальные вопросы неврологии и нейрохирургии : материалы VI научно-практической конференции. - Ростов-на-Дону, 2008. - С. 41.

21. Renton Tara. Managing iatrogenic trigeminal nerve injury: a case series and reviewof the literature / Tara Renton // Int. J. Oral Maxillofac. Surg. - 2012. - No. 5. P 10-19.

\section{References}

1. Braslavets, A.Ya. (2006). Neotlozhnaya nevrologiya: uchebnoe posobye dlya studentov, vrachey internov, klinicheskykh ordinatorov, magistrov [Emergency Neurology: study guide]. Kharkov [in Russian]. 2. Voskresenskaya, O.N., \& Damulin, I.V. (2015). Sotryaseniye golovnogo mozga: klinika, diagnostika, lecheniye [Concussion of the brain: clinic, diagnosis, treatment]. Rosiyskiy meditsinskiy zhurnal - Russian Medical Journal, (5), 53-56 [in Russian].

3. Gusev, E.Y., Konovalov, A.N., Skvortvova, V.Y., \& Gext, A.B. (2009). Nevrologiya. Natsyonalnoye rukovodstvo [Neurology: national guide]. Moscow: GEOTAR-Media.

4. Eliseeva, E.V., Gandylyan, K.S. \& Karpov, S.M. (2014). Struktura travm chelyustno-litsevoy oblasti na primere g. Stavropolya [The structure of injuries of the maxillofacial region on the example of the city of Stavropol]. Aktualnyye voprosy stomatologii: 49 Vserossiyskaya nauch.-prakt. konferentsiya: materialy konf. - Current Issues of Dentistry: 49th All-Ukrainian Scientific Practical Conference: Materials of Conference. Stavropol (pp. 211-214) [in Russian].

5. Karlov, V.A.(2011) Nevrologiya: rukovodstvo dlya vrachey [Neurology: doctors guide]. Moscow: Medinformagentstvo [in Russian].

6. Lepilin, A.V., Bakhtyeyeva, G.R., \& Erokina, N.L. (2007). Primeneniye chreskozhnoy elektroneyrostimulyatsii $\mathrm{v}$ komplekse lecheniya bolnykh $\mathrm{s}$ perelomami nizhney chelyusti [The use of percutaneous electroneurostimulation in the treatment of patients with mandibular fractures]. Stomatologiya - Dentistry, 87 (2), 54-56 [in Russian].

7. Mokryk, O.Ya., \& Nazarevych, M.R. (2012). Suchasni dosiahnennia fizioterapevtychnoho likuvannia bolovoho sundromu u khvorykh iz patolohichnymy protsesamy v shchelepno-lytseviy dilyantsi [Modern achievements of hysiotherapeutic treatment of pain syndrome in patients with pathological processes in the maxillofacial area]. Medychna hidrolohiia ta reabilitatsiia - Medical Hydrology and Rehabilitation, 10 (1), 19-23 [in Ukrainian].

8. Nazarevych, M.R. (2017). Retrospektyvne vyvchennia
22. Renton Tara. Prevention of iatrogenic inferior alveolar nerve injuries in relation to dental procedures / Tara Renton // British Dent. Update. - 2010. - No. 37. P. 350-363.

23. Susarla Srinivas M. Third molar surgery and associated complications / M. Srini-vas Susarla, Bart F. Blaeser, Daniel Magalnick // Oral Maxillofacial Surg. Clin. - 2003. - No. 15. - P. 177-186.

24. Шутеева Т. В. Коррекция болевого синдрома при диабетической нейропатии: современный взгляд на проблему / Т. В. Шутеева // Современные проблемы науки и образования. - 2018. - № 3. - Peжим доступа http://www.science-education.ru/ru/ article/view?id=27578 (дата обращения: 13.07.2019). Назва с экрана.

25. Фурман Р. Л. Вплив нуклеотидних препаратів на відновлення провідності інфраорбітального нерва при переломах виличної кістки / Р. Л. Фурман, С. С. Поліщук, О. В. Кузько // Современная стоматология. - 2016. - № 4. - С. 60-63.

osoblyvostei poshkodzhen kistok serednoi zony oblychchia u statsionarnykh khvorykh ta zastosovanykh pidkhodiv do yikh likuvannia [Retrospective study of peculiarities of middle body bone lesions in stationary patients and applied approaches to their treatment]. Aktualni problemy suchasnoi medytsyny: visnyk ukrainskoi medychnoi stomatolohichnoi akademii - Current Issues of Modern Medicine: Bulletin of Ukrainian Medical Dental Academy, 17 (2), 132-136 [in Ukrainian].

9. Vinychuk, S.M., \& Dubenko, Ye.H. (Eds.). (2001). Nervovi khvoroby [Nervous diseases]. Kyiv: Zdorovia [in Ukrainian].

10. Sivolapov, K.A., \& Kharchenko, E.V. (2001). Klinikosotsialnye aspekty travmaticheskikh povrezhdeniy sredney zony litsa [Clinical and social aspects of traumatic injuries of the midface]. Aktualnye problemy stomatologii $i$ smezhnykh oblastey: materyaly nauch.prakt. konf. - Current Issues of Dentistry and Adjacent Regions: Materials of Scientific and Practical Conference. Novosibirsk [in Russian].

11. Timofyeyev, A.A., \& Lesnukhin, V.L. (2009). Izucheniye sostoyaniya nizhego alveolyarnogo nerva pri povrezhdeniyakh nizhney chelyusti $\mathrm{v}$ dinamike provodimogo lecheniya. Chast 1 . [The study of the state of the lower alveolar nerve in case of damage to the mandible in the dynamics of the treatment. Part 1]. Sovremennaya stomatologiya - Modern Dentistry, (3), 109-115 [in Russian].

12. Timofyeyev, A.A., \& Lesnukhin, V.L. (2009). Izucheniye sostoyaniya nizhego alveolyarnogo nerva pri povrezhdeniyakh nizhney chelyusti $\mathrm{v}$ dinamike provodimogo lecheniya. Chast 2. [The study of the state of the lower alveolar nerve in case of damage to the mandible in the dynamics of the treatment. Part 2]. Sovremennaya stomatologiya - Modern Dentistry, (4), 76-80 [in Russian].

13. Timofyeyev, A.A., \& Vesova, E.P. (2006). Izpolzovaniye tsvetnoy stereokitografii $\mathrm{v}$ diagnostike porazheniy perifericheskikh vetvey troynichnogo nerva [The use of color stereolithography in the diagnosis of lesions 
of the peripheral branches of the trigeminal nerve]. Sovremennaya stomatologiya - Modern Dentistry, (1), 113-116 [in Russian].

14. Timofyeyev, A.A., \& Vesova, E.P. (2010). Klinikopatofiziologicheskiye podkhody $\mathrm{k}$ klassifikatsii porezheniy v sisteme troynichnogo nerva [Clinical and pathophysiological approaches to the classification of lesions in the trigeminal nerve system]. Sovremennaya stomatologiya - Modern Dentistry, (4), 100-101 [in Russian].

15. Tymofyeyev, A.A. (2012). Rukovodstvo po chelyustnolytsevoy khirurgii $i$ khirurggicheskoy stomatologii [Manual for maxillofacial surgery and surgical dentistry]. Kyiv [in Russian].

16. Tymofyeyev, A.A. (2010). Chelyustno-lytsevaya khirurgiya [Maxillofacial surgery]. Kyiv: Medytsyna [in Russian].

17. Umarov, O.M. (2012). Obshchaya statisticheskaya kharakteristika sochetannoy travmy chelyustnolitsevoy oblasti [General statistical characteristic of the combined injury of the maxillofacial area]. Vrach aspirant - Doctor - Aspirant, 50 (1), 221-224 [in Russian]. 18. Malanchuk, V.O., Volovar, O.S., \& Garlyauskayte, I.Yu. (2011). Khirurhichna stomatolohiia ta shchelepnolytseva khirurhiia: pidruchnyk. T. 1 [Manual for surgical dentistry and maxillofacial surgery. Vol. 1]. Kyiv: LOHOS [in Ukrainian].

19. Robustova, T.G. (Ed.). (2010). Khirurgicheskaya stomatologiya: uchebnik [Manual for surgical dentistry]. Moscow: Meditsyna [in Russian].

20. Tsukurova, L.A., Barabanova, M.A., \& Muzlayev, G.T. (2008). Transkranialnaya elektrostimulyatsiya pri lechenii bolnykh $\mathrm{s}$ ishemicheskim insultom $\mathrm{v}$ rannem vosstanovitelnom periode [Transcranial electrostimulation in the treatment of patients with ischemic stroke in the early recovery period]. Aktualnye voprosy nevrologii $i$ neyrokhirurgii: materialy VI nauchno-prakticheskoy konferentsii - Current Issues of Neurology and Neurosurgery: Materials of VI ScientificPractical Conference. Rostov on Don [in Russian].

21. Renton Tara (2012). Managing iatrogenic trigeminal nerve injury: a case series and reviewof the literature. Int. J. Oral Maxillofac. Surg, (5),10-19.

22. Renton Tara (2010). Prevention of iatrogenic inferior alveolar nerve injuries in relation to dental procedures. British Dent. Update,37, 350-363.

23. Susarla Srinivas M., Bart F. Blaeser \& Daniel Magalnick (2003). Third molar surgery and associated complications. Oral Maxillofacial Surg. Clin., 15, 177-186. 24. Shuteyeva, T.V. (2018). Korrektsiya bolevogo sindroma pri diabeticheskoy neyropatii: sovremennyy vzglyad na problemu [Correction of pain syndrome in diabetic neuropathy: a modern view of the problem]. Sovremennyye problemy nauki i obrazovaniya - Modern Problems of Science and Education], (3). Retrieved from: http://www.science-education.ru/ru/article/ view?id=27578 [in Russian].

25. Furman, R.L., Polishchuk, S.S. \& Kuzko, O.V. (2016). Vplyv nukleotydnykh preparative na vidnovlennya providnosti infraorbitalnogo nerva pry perelomakh vylychnoi kistky [Influence of nucleotide preparations on restoration of conduction of infraorbital nerve in cervical bone fractures]. Sovremennaya stomatologiya Modern Dentistry, (4), 60-63 [in Ukrainian].

Отримано 04.06.19 